\title{
Introduction to the 2021 Special Section Theme: Global Perspectives on Health Sciences Education
}

\author{
Peter G. M. de Jong ${ }^{1}$ \\ Published online: 29 November 2021 \\ (c) The Author(s) under exclusive licence to International Association of Medical Science Educators 2021
}

In 2015, Medical Science Educator introduced "journal sections" on a specific topic. These thematic sections are the successor of the special issues that were published annually in the years before. The content for the thematic sections is solicited by a special call for manuscripts. This year, we are publishing a special journal section dedicated to the topic of "Global Perspectives on Health Sciences Education."

Health and disease are not limited by borders or continents. The world is facing major challenges caused by diseases of global importance and the impact of genetics, behavior, environmental and physical influences, medical care, and social factors on health. Obviously, health care education worldwide needs to adapt to these developments. In this 2021 special section, the journal explores international aspects and best practices of medical education from around the world.
The journal received over 20 submissions for this special journal section. In this issue of Medical Science Educator, I present to you the first 7 published manuscripts. Some manuscripts are still in revision or production and will be published in one of the upcoming regular journal issues. I hope that the articles in this section are of interest to you and will be an inspiration for medical education leaders to help shaping the future.

Peter GM de Jong, PhD

Editor-in-Chief

Publisher's Note Springer Nature remains neutral with regard to jurisdictional claims in published maps and institutional affiliations.

Peter G. M. de Jong

P.G.M.de_Jong@lumc.nl

1 Leiden University Medical Center, Leiden, The Netherlands 